\title{
VALIDATION OF CROATIAN VERSION OF DEMENTIA ATTITUDES SCALE (DAS)
}

\author{
Bojana Ćoso \\ Sveučilište u Rijeci, Filozofski fakultet, Odsjek za psihologiju \\ Sveučilišna avenija 6, 51000 Rijeka \\ coso.bojana@gmail.com \\ bojana.coso@psihogerontologija.hr \\ Suzana Mavrinac \\ Alma Mater Europaea Maribor \\ Slovenska ulica 17, 2000 Maribor, Slovenija \\ suzanamavrinac@gmail.com \\ suzana.mavrinac@psihogerontologija.hr
}

\begin{abstract}
Dementia significantly impairs cognitive and behavioral functioning of the person, and in recent years there has been a significant increase in the number of patients suffering from dementia. In Croatia, such patients are often placed in retirement homes, non-specialized institutions for the elderly and infirm, often without adequately educated employees. Attitudes toward dementia seem to be an important factor for adequate care of people with dementia, but there was no previous research on this topic in Croatia. The Dementia Attitudes Scale (DAS) developed by O'Connor and McFadden (2010), is a useful tool in research of attitudes toward dementia. The aim of the study was to translate the scale into the Croatian language and validate it on a Croatian sample. Participants were employees and retirement home users, other health care workers and the general population. Validation conducted on samples that were in everyday contact with dementia patients showed consistent factors (social comfort and dementia knowledge) as in the original scale, so the conclusion was that the questionnaire could be used in that population. Still, overall results that included the general sample showed different factors when compared to the original scale, since the Croatian version did not show standard factors, but rather positive and negative attitudes factors. Results could be seen as highly suggestive and emphasize the need to distinguish and separate research on attitudes toward dementia in different populations.
\end{abstract}

Key words: attitudes toward dementia, Dementia attitudes scale, dementia knowledge, social comfort 


\section{INTRODUCTION}

More than ten years ago, dementia was identified as one of four gerontological public health problems in the elderly in Croatia (Perko, Tomek-Roksandić, Mihok, Puljak, Radašević, Tomić \& Čulig, 2005), mostly because of the significant increase in the number of patients suffering from the disease (Gilić, Perinčić \& Kovač, 2008). Because of demographic changes, this trend can be seen in most European countries, for example, in Germany (Doblhammer, Fink \& Fritze, 2015; Ziegler \& Doblhammer, 2009), but also in China and sub-Saharan African regions (Wortmann, 2014), as well as Australia (McCabe, You \& Tatangelo, 2016) and South Korea (Shin, Seo, Kim, Kim \& Lee, 2015). Dementia affects not only patients, but also families and caregivers. Research showed that significant cognitive impairment is often associated with uncertainty and worries of the patient (Samsi \& Manthorpe, 2014) and their willingness to talk about the diagnosis only with family members (Langdon, Eagle \& Warner, 2007) which creates a problem when these patients are separated from their families and familiar environment. Often, family members are unable to care for their relatives even in the first stages of dementia, thus forcing relatively young patients in the first stage of the disease to be placed in homes for the elderly and infirm. As relations between patients and employees have a crucial role in the patients well-being (Bowers, Esmond \& Jacobson, 2000), authors often emphasize the importance of adequately educated employees (Gustin, Žuvela, Jerinić, Roso \& Kunić, 2015; Nakahira, Moyle, Creedy \& Hitomi, 2009; Perko et al., 2005). At the same time, organizational and practical problems shouldn't be neglected, as it was found that sometimes these factors can cause aggressive behavior in patients (Nakahira et al., 2009). In general, research of attitudes toward the elderly showed lower social attractiveness (Kite, Stockdale, Whitley \& Johnson, 2005), and such attitudes can influence and affect how people interact with them. At the same time, patients suffering from dementia were evaluated in a more negative than a positive way (Askham, 1995; Brodaty, Draper \& Low, 2003), and more negative on semantic attitude scale when compared to other healthy older people (Kahana, Kinney, Kercher, Kahana, Tinsley, King, Stuckey \& Ishler, 1996). With these results in mind, attitudes toward dementia seem like an important factor in an effort to improve care and well-being of patients suffering from dementia. Also, it seems important to have adequate tools for the research of attitudes toward dementia in people with everyday contact with patients suffering from the disease. So far, there has not been research about attitudes toward dementia in Croatia, nor were the foreign questionnaires ever validated.

\section{Attitudes toward dementia}

Attitudes have three basic components: cognitive, affective and behavioral (e.g. Breckler, 1984; Ostrom, 1969). Cognitive component mostly refers to knowledge 
(or beliefs) about the object, while the affective component refers to a persons emotions toward the object. Thirdly, the behavioral component is sometimes the result of the previous two and manifests as a behavior toward object based on knowledge (beliefs) and emotions toward object. Nurses' attitudes toward patients, as well as their attitudes toward work have a significant impact on the quality of nursing care (Norbergh, Helin, Dahl, Hellzen \& Asplund, 2006). Moreover, negative attitudes toward patients suffering from dementia were linked to lower satisfaction with work (Moyle, Murfield, Griffiths \& Venturato, 2011) and simultaneously with less effort and care toward patients (Brodaty, Draper \& Low, 2003), and are in a negative correlation with Burnout-syndrome (Astrom, Nilsson, Norberg, Sandman \& Winblad, 1991). Attitudes toward dementia were widely examined, and there are few questionnaires dealing with attitudes toward dementia, but none of them cover the entire construct (O'Connor \& McFadden, 2010). Approaches to Dementia Questionnaire (ADQ; Lintern, Woods \& Phair, 2000) consists of statements about people with dementia and their care. The questionnaire consists of 19 items and answers on a 5-point Likert scale, with two factors, hope and recognition of personhood. Although ADQ is in use in research (e.g. Kada, Nygaard, Mukesh \& Geitung, 2009; Zimmerman, Williams, Reed, Boustani, Preisser, Heck \& Sloane, 2005), as well as with United Kingdom's health care homes' staff, O'Connor and McFadden (2010) emphasize the lack of a more general scale. Another Likert scale was used by Lundquist and Ready (2008) but they measured only sympathy and willingness to help individuals with $A D$. Cognitive attitudes were not covered by the scale. As participants were only undergraduate students, external validity of this research is also questionable. In another research, semantic differential technique was used (Norbergh et al., 2006), but again, the focus of the study was only on the affective component. Attitudes toward dementia are sometimes investigated by scales that refer to related topics, e.g. staff's aggression with the Attitudes Towards Aggression Scale (Nakahira et al., 2009) and strain and attitudes by Swedish Strain in Nursing Care Assessment Scale (Brodaty, Draper \& Low, 2003; Kleinman, Frank, Ciesla, Rupnow \& Brodaty, 2004).

\section{Dementia attitudes scale (DAS)}

Dementia attitudes scale (DAS) was designed by O'Connor and McFadden (2010), based on three partite model of attitude: cognitive, behavioral and affective (Breckler, 1984). Creation of the scale consisted of four phases. In the first phase, authors provided structured interviews with the fifteen participants; five of them were caregivers, five were professionals in the dementia care field and five were students. Interviews were structured by open-ended questions which referred to general knowledge about Alzheimer's disease and related disorders (ADRD), as well as perception of patients and their own potential behavior in contact with 
agitated person suffering from dementia. In the second stage, forty-six-item scale was derived from participant's answers. Out of 46 items, one third referred to every component (cognitive, behavioral and affective). First version of DAS was given to 307 participants, and following factor analysis, 16 items were removed from the scale. Again, 30-item scale was given to 145 participants. Principal axis factoring with Oblimin rotation reduced DAS on 20 items and two loaded factors, dementia knowledge and social comfort. Two factors explained $38.72 \%$ of the variance, and Cronbach alpha for the remaining 20 items was 0.85; dementia knowledge, $\alpha=0.75$, and social comfort, $\alpha=0.82$. Factor 1 , social comfort, from Dementia Attitudes Scale refers to a cognitive domain of attitudes and twenty items loaded on factor. Six of them are reverse scored. Factor 2, dementia knowledge, refers to affective and behavioral domains of attitudes, which merged into one factor. There are no reverse scored items in dementia knowledge factor. Authors replicated DAS with the two different samples and the structure of the Scale remained unchanged.

Furthermore, replication across two different samples, considered the strong side of DAS by O'Connor and McFadden (2010), is a combination of qualitative and quantitative methods in construction of the scale. At the same time, unlike previous models, it was based on tripartite model of attitudes, which was a major drawback for existing scales and dementia attitudes questionnaires.

\section{Present study}

Attitudes toward dementia were not previously researched in Croatia, despite the fact that similar studies are constantly being conducted in numerous countries. Moreover, health care staff in the UK are monitored by the Approaches to Dementia Questionnaire. As mentioned before, dementia was identified as one of four major gerontological-public health problems in the elderly in Croatia (Perko et al., 2005) but there is still no structured research and educational plan for health care employees, family members and the general population. There has been a significant change when it comes to accommodating patients suffering from dementia in recent years. Until recently, such patients were mostly accommodated in psychiatric institutions together with other psychiatric patients, and some institutions had up to $40 \%$ of patients suffering from one form of dementia (Gustin et al., 2015; Perko et al., 2005). Nowadays, patients are mostly placed in homes for the elderly and infirm, which sometimes have more than $20 \%$ of users with diagnosed dementia, so Gustin et al. (2015) emphasize the need for highly specialized institutions for patients suffering from dementia, as well as additionally educated employees. It is anticipated that the proportion will only increase, and will eventually reach $40 \%$ of retirement homes' users (as in USA, Zimmerman \& Sloane, 1999). Recently, some private nursing homes for the elderly and infirm in Croatia opened special wards for patients suffering from dementia, but without properly educated employees and 
legitimate regulations from the government. Research from Hong Kong showed that nursing staff working in private institutions are often less educated and work longer hours, which has shown to be a significant factor in managing behavioral problems of patients, such as yelling or aggression (Leung, Sezto, Chan, Cheng, Tang \& Lam, 2013). Thus, research on attitudes toward dementia with an adequate questionnaire seems crucial for progress and well-being of patients with dementia. This questionnaire specially refers to employees in homes for the elderly and infirm, but there is also a need to gather data from other populations. Non-nursing staff, as well as other users in retirement homes are rarely the subject of research, although they are also in everyday contact with patients suffering from dementia. Finally, due to a significant increase in number of patients suffering from dementia, the general population and their attitudes toward dementia should also be taken into account.

\section{METHOD}

\section{Participants}

A total of 223 participants were included in the study: 111 health care employees (81 medical and 30 non-medical), 77 examinees from the general population and 35 users of homes for the elderly and infirm completed the Croatian version of Dementia attitudes scale. Almost half of the participants from the general population had contact with dementia patient in the last six months (35 examinees), and 42 did not have any contact. In total, there were 60 male and 163 female participants, ranging in age from 19 to 90. Research was conducted in Home for elderly and infirm persons Vitanova in Viškovo and Family home for elderly and infirm persons Marija Brekalo in Dugo Selo. General population participants were collected by convenience sampling through e-mail addresses (authors' contacts) and in Vitanova home. Research was anonymous and participants were familiar with the aim of the study. Participants gave voluntary consent to participate in the study.

\section{Instruments}

Croatian version of Dementia attitudes scale consisted of 20 items from the original scale, translated into Croatian and adjusted for group of participants. There were two kinds of adjustments. For non-health care workers, users and general population item no 8 was changed to It is rewarding to associate with people who have ADRD instead original It is rewarding to work with people who have ADRD. Second change was in the layout, there was greater space between items and bigger letters for users in homes for the elderly and infirm. Both Croatian and original 
Table 1. English and Croatian version of items in Dementia attitudes scale

\begin{tabular}{|c|c|}
\hline English - Dementia attitudes scale & Croatian - Skala stavova o demenciji \\
\hline I feel confident around people with ADRD. & $\begin{array}{l}\text { Osjećam se samopouzdano u blizini osoba s } \\
\text { demencijom. }\end{array}$ \\
\hline I am comfortable touching people with ADRD. & Mogu ležerno dodirivati osobe s demencijom. \\
\hline $\begin{array}{l}\text { I feel uncomfortable being around people with } \\
\text { ADRD. }\end{array}$ & $\begin{array}{l}\text { Ne osjećam se ležerno u blizini osobe s } \\
\text { demencijom. }\end{array}$ \\
\hline I am not very familiar with ADRD. & Nisam dovoljno upoznat s demencijom. \\
\hline I would avoid an agitated person with ADRD. & $\begin{array}{l}\text { Izbjegao bi kontakt s uzrujanom osobom s } \\
\text { demencijom. }\end{array}$ \\
\hline I feel relaxed around people with ADRD. & $\begin{array}{l}\text { Osjećam se opušteno u blizini osoba s } \\
\text { demencijom. }\end{array}$ \\
\hline $\begin{array}{l}\text { I feel frustrated because I do not know how to } \\
\text { help people with ADRD. }\end{array}$ & $\begin{array}{l}\text { Frustriran sam jer ne znam kako pomoći } \\
\text { osobama s demencijom. }\end{array}$ \\
\hline $\begin{array}{l}\text { It is rewarding to work with people who have } \\
\text { ADRD. }\end{array}$ & Nagrađujuće je raditi s osobama s demencijom. \\
\hline $\begin{array}{l}\text { I cannot imagine caring for someone with } \\
\text { ADRD. }\end{array}$ & $\begin{array}{l}\text { Ne mogu zamisliti da se moram brinuti o osobi } \\
\text { s demencijom. }\end{array}$ \\
\hline I am afraid of people with ADRD. & Bojim se osoba s demencijom. \\
\hline & \\
\hline Every person with ADRD has different needs. & $\begin{array}{l}\text { Svaka osoba s demencijom ima različite } \\
\text { potrebe. }\end{array}$ \\
\hline $\begin{array}{l}\text { People with ADRD like having familiar things } \\
\text { nearby. }\end{array}$ & $\begin{array}{l}\text { Osobe s demencijom vole imati poznate } \\
\text { predmete u blizini. }\end{array}$ \\
\hline $\begin{array}{l}\text { It is important to know the past history of } \\
\text { people with ADRD. }\end{array}$ & $\begin{array}{l}\text { Važno je znati protekli život osoba s } \\
\text { demencijom. }\end{array}$ \\
\hline $\begin{array}{l}\text { It is possible to enjoy interacting with people } \\
\text { with ADRD. }\end{array}$ & $\begin{array}{l}\text { Moguće je uživati u druženju s osobama s } \\
\text { demencijom. }\end{array}$ \\
\hline People with ADRD can enjoy life. & Osobe s demencijom mogu uživati u životu. \\
\hline $\begin{array}{l}\text { People with ADRD can feel when others are } \\
\text { kind to them. }\end{array}$ & $\begin{array}{l}\text { Osobe s demencijom mogu osjetiti kada je } \\
\text { netko dobar prema njima. }\end{array}$ \\
\hline $\begin{array}{l}\text { We can do a lot now to improve the lives of } \\
\text { people with ADRD. }\end{array}$ & $\begin{array}{l}\text { Možemo učiniti mnogo kako bi poboljšali život } \\
\text { osoba s demencijom. }\end{array}$ \\
\hline $\begin{array}{l}\text { I admire the coping skills of people with } \\
\text { ADRD. }\end{array}$ & $\begin{array}{l}\text { Divim se vještinama suočavanja s bolesti kod } \\
\text { osoba s demencijom. }\end{array}$ \\
\hline $\begin{array}{l}\text { Difficult behaviors may be a form of } \\
\text { communication for people with ADRD. }\end{array}$ & $\begin{array}{l}\text { Teško ponašanje može biti način komunikacije } \\
\text { osoba s demencijom. }\end{array}$ \\
\hline
\end{tabular}

English items are shown in Table 1, with the permission of the copyright owner, Melissa O'Connor.

Items were ordered as in the original scale. Fourteen items had positive and six items had negative polarity. Before conducting factor analysis, all items were transposed into the same polarity. In total data, there were no answers for only 25 items, which was less than $0.006 \%$ missing values. Because of low proportion of missing items, they were estimated using participant's own mean value, depending on fac- 
tor from the English version of Dementia attitudes scale. English version of DAS referred to Alzheimer's disease and related disorders (ADRD) because of authors concern that referring only to dementia would make participants ask if Alzheimer's disease is a dementia related disorder (O'Connor \& McFadden, 2010). Since in Croatia only a small part of participants with diagnosed Alzheimer's disease live in homes for elderly and infirm, and there are special wards for patients suffering from dementia, Croatian scale contains word dementia instead of ADRD. Therefore, verbal instructions contained information about dementia as both, vascular and Alzheimer's type.

In addition, participants completed a questionnaire containing demographic data, as well as one on their opinion about adequacy of education about dementia, emotions they attach to old age and competence of Institutions and workers who take care of elderly people in their region. They also answered the question "Did you have contact with person suffering from dementia in the last six months?"

\section{Procedure}

Research was conducted individually, with a short verbal introduction to the research aims and instructions for completing the questionnaire. Majority of instructions were verbal, but the participants who received the scale through e-mail got written instructions. Medical and non-medical employees completed the scale at their work place, and home users completed it in their rooms.

\section{RESULTS}

Descriptive statistics, correlations and reliability

Possible range on the scale was between 20 and 100, and total score on the scale ranged from $\min 43$ to $\max 94(M=70.56, S D=9.59)$. Items descriptive statistics showed a wide range of means, but most of the items had $M$ range from 3.44 to 4.13 (14 items). Six items $M$ ranged from 2.81 to 3.26, and $M$ values indicated normal distribution of the results. Maximum and minimum values covered complete range from 1 to 5 in all scale items. Complete descriptive statistics are shown in Table 2, and items intercorrelations are shown in Table 3.

Most of the participants indicated their contact with person suffering from dementia $(81.2 \%, N=181)$, and all participants working in health system stated they had contact with such patients in the last six months. Cronbach alpha for DAS scale was 0.847 .

To indicate the variables that could have affected scale validation, three one-way ANOVAs were performed, investigating general attitudes toward dementia with re- 
Table 2. Descriptive statistics for DAS items $(N=223)$

\begin{tabular}{|c|c|c|c|c|}
\hline & $M$ & $S D$ & Max & Min \\
\hline Nagradujuće je raditi s osobama s demencijom. & 3.01 & 0.97 & 1 & 5 \\
\hline Bojim se dementnih osoba. & 4.13 & 0.78 & 1 & 5 \\
\hline Osobe s demencijom mogu biti kreativne. & 3.65 & 0.74 & 1 & 5 \\
\hline Osjećam se samopouzdano u blizini dementnih osoba. & 2.81 & 1.02 & 1 & 5 \\
\hline Mogu ležerno dodirivati osobe s demencijom. & 3.62 & 0.99 & 1 & 5 \\
\hline Ne osjećam se ležerno u blizini osobe s demencijom. & 3.79 & 1.05 & 1 & 5 \\
\hline Svaka osoba s demencijom ima različite potrebe. & 3.97 & 0.89 & 1 & 5 \\
\hline Nisam dovoljno upoznat s demencijom. & 2.95 & 1.15 & 1 & 5 \\
\hline Izbjegao bi kontakt s uzrujanom dementnom osobom. & 3.16 & 1.14 & 1 & 5 \\
\hline $\begin{array}{l}\text { Osobe s demencijom vole imati poznate predmete u } \\
\text { blizini. }\end{array}$ & 3.64 & 0.90 & 1 & 5 \\
\hline Važno je znati protekli život dementne osobe. & 3.70 & 0.88 & 1 & 5 \\
\hline Moguće je uživati u druženju s dementnom osobom. & 3.65 & 0.91 & 1 & 5 \\
\hline Osjećam se opušteno u blizini dementnih osoba. & 3.13 & 0.92 & 1 & 5 \\
\hline Dementne osobe mogu uživati u životu. & 3.55 & 0.85 & 1 & 5 \\
\hline $\begin{array}{l}\text { Dementne osobe mogu osjetiti kada je netko dobar } \\
\text { prema njima. }\end{array}$ & 3.94 & 0.88 & 1 & 5 \\
\hline $\begin{array}{l}\text { Frustriran sam jer ne znam kako pomoći dementnim } \\
\text { osobama }\end{array}$ & 3.26 & 1.01 & 1 & 5 \\
\hline $\begin{array}{l}\text { Ne mogu zamisliti da se moram brinuti o dementnoj } \\
\text { osobi. }\end{array}$ & 3.44 & 1.06 & 1 & 5 \\
\hline $\begin{array}{l}\text { Divim se vještinama suočavanja s bolesti kod dementnih } \\
\text { osoba }\end{array}$ & 3.69 & 0.94 & 1 & 5 \\
\hline $\begin{array}{l}\text { Možemo učiniti mnogo kako bi poboljšali život } \\
\text { dementnih osoba. }\end{array}$ & 4.00 & 0.89 & 1 & 5 \\
\hline $\begin{array}{l}\text { Teško ponašanje može biti način komunikacije } \\
\text { dementnih osoba. }\end{array}$ & 3.48 & 0.91 & 1 & 5 \\
\hline
\end{tabular}

gard to participants' contact with persons suffering from dementia, gender and age. One way ANOVA showed no differences between participants who were in contact with person suffering from dementia $(M=71.00, S D=9.92)$ and those who were not $(M=68.63, S D=7.85)$ in general attitudes toward dementia scores, $F(1,221)$ $=2.09, p=0.150$. Also, ANOVA did not show significant differences between male $(M=70.30, S D=10.04)$ and female $(M=70.65, S D=9.45)$ participants in general attitudes toward dementia, $F(1,221)=0.59, p=0.809$. As previous variables, ANOVA did not show differences in general attitudes toward dementia depending on age, $F(1,68)=0.59, p=0.809$ 


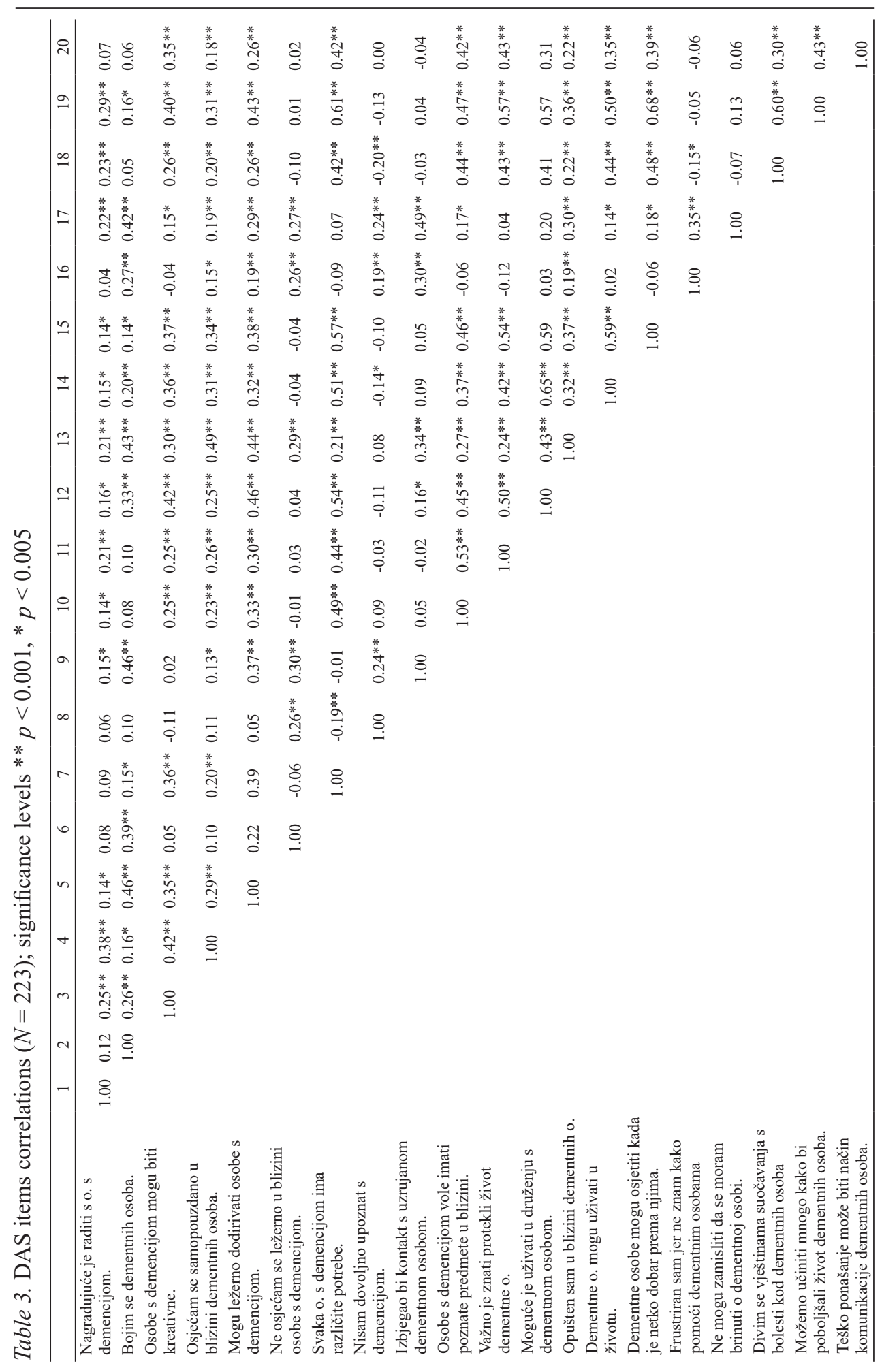

(C) "Naklada Slap", 2016. Sva prava pridržana. 


\section{Factor analysis on complete sample}

Despite the clear structural form in the original Dementia attitudes scale that loaded two factors (social comfort and dementia knowledge), both exploratory and confirmatory factor analysis were made. Decision on exploratory factor analysis was made due to the lack of research on attitudes toward dementia on Croatian sample. First Principal factor analysis with Oblimin rotation extracted four factors with Eigenvalue $>1$ and $57.36 \%$ of total variance explained. Further analysis found that only one item loaded on third factor, while none of the items loaded exclusively on forth factor (Table 4). Croatian items It is rewarding to work with people who have ADRD, and I am not very familiar with ADRD loaded on two factors. Factor correlation matrix is shown in Table 5.

Table 4. Exploratory factor analysis which loaded 4 factors with Eigenvalue $>1(N=223)$

\begin{tabular}{|c|c|c|c|c|}
\hline & \multicolumn{4}{|c|}{ FACTORS } \\
\hline & 1 & 2 & 3 & 4 \\
\hline Možemo učiniti mnogo kako bi poboljšali život dementnih osoba. & .79 & & & \\
\hline Moguće je uživati u druženju s dementnom osobom. & .76 & & & \\
\hline Dementne osobe mogu osjetiti kada je netko dobar prema njima. & .76 & & & \\
\hline Dementne osobe mogu uživati u životu. & .68 & & & \\
\hline Svaka osoba s demencijom ima različite potrebe. & .68 & -.27 & & \\
\hline Važno je znati protekli život dementne osobe. & .64 & & & \\
\hline Osobe s demencijom vole imati poznate predmete u blizini. & .62 & & & .38 \\
\hline Mogu ležerno dodirivati osobe s demencijom. & 60 & .30 & & \\
\hline Divim se vještinama suočavanja s bolesti kod dementnih osoba & .57 & -.32 & & \\
\hline Osjećam se opušteno u blizini dementnih osoba. & .56 & .37 & & \\
\hline Osobe s demencijom mogu biti kreativne. & .54 & & & \\
\hline Teško ponašanje može biti način komunikacije dementnih osoba. & .51 & & & \\
\hline Nagradujuće je raditi s osobama s demencijom. & .31 & & .28 & \\
\hline Izbjegao bi kontakt s uzrujanom dementnom osobom. & & .63 & & \\
\hline Bojim se dementnih osoba. & .38 & .58 & & \\
\hline Ne mogu zamisliti da se moram brinuti o dementnoj osobi. & .29 & .56 & & \\
\hline Ne osjećam se ležerno u blizini osobe s demencijom. & & .50 & & \\
\hline Frustriran sam jer ne znam kako pomoći dementnim osobama & & .50 & & \\
\hline Nisam dovoljno upoznat s demencijom. & & .41 & & .46 \\
\hline Osjećam se samopouzdano u blizini dementnih osoba. & .52 & & .72 & \\
\hline Eigenvalue & 6.15 & 2.95 & 1.22 & 1.16 \\
\hline$\%$ of variance explained & 30.73 & 14.74 & 6.11 & 5.78 \\
\hline
\end{tabular}


Table 5. Four factors correlation matrix $(N=223)$

\begin{tabular}{lrrrr}
\hline & \multicolumn{4}{c}{ FACTORS } \\
\cline { 2 - 5 } & \multicolumn{1}{c}{1} & \multicolumn{1}{c}{2} & \multicolumn{1}{c}{3} & \multicolumn{1}{c}{4} \\
\hline Factor 1 & 1.000 & .123 & .442 & -.284 \\
Factor 2 & .123 & 1.000 & .341 & .088 \\
Factor 3 & .442 & .341 & 1.000 & -.075 \\
Factor 4 & -.284 & .088 & -.075 & 1.000 \\
\hline
\end{tabular}

As explanatory factor analysis didn't show clear factors of Dementia attitudes scale, confirmatory factor analysis with Oblimin rotation was made in the second step. Analysis was made without Croatian items It is rewarding to work with people who have ADRD, and I am not very familiar with ADRD that in explanatory analysis

Table 6. Confirmatory factor analysis with two factors $(N=223)$

\begin{tabular}{llcc}
\hline & FACTORS & Commu- \\
\cline { 2 - 3 } & 1 & 2 & nalities \\
\hline Možemo učiniti mnogo kako bi poboljšali život dementnih osoba. & .79 & & .67 \\
Dementne osobe mogu osjetiti kada je netko dobar prema njima. & .77 & .62 \\
Moguće je uživati u druženju s dementnom osobom. & .76 & .58 \\
Svaka osoba s demencijom ima različite potrebe. & .68 & .52 \\
Dementne osobe mogu uživati u životu. & .68 & & .47 \\
Važno je znati protekli život dementne osobe. & .64 & .47 \\
Osobe s demencijom vole imati poznate predmete u blizini. & .61 & & .40 \\
Mogu ležerno dodirivati osobe s demencijom. & .60 & .32 & .47 \\
Divim se vještinama suočavanja s bolesti kod dementnih osoba & .57 & -.31 & .43 \\
Osjećam se opušteno u blizini dementnih osoba. & .56 & .38 & .45 \\
Osobe s demencijom mogu biti kreativne. & .52 & & .28 \\
Teško ponašanje može biti način komunikacije dementnih osoba. & .51 & & .30 \\
Osjećam se samopouzdano u blizini dementnih osoba. & .45 & & .23 \\
Izbjegao bi kontakt s uzrujanom dementnom osobom. & & .63 & .44 \\
Bojim se dementnih osoba. & .37 & .60 & .51 \\
Ne mogu zamisliti da se moram brinuti o dementnoj osobi. & .28 & .55 & .38 \\
Frustriran sam jer ne znam kako pomoći dementnim osobama & & .50 & .25 \\
Ne osjećam se ležerno u blizini osobe s demencijom. & & .49 & .25 \\
\hline \multicolumn{1}{c}{ \%igenvalue } & 6.04 & 2.78 & \\
\hline & 33.58 & 15.43 & \\
\hline
\end{tabular}


loaded on two factors. Principal factors analysis with Oblimin rotation showed that two factors explain $49.01 \%$ of total variance. Kaiser-Meyer-Olkin measure (KMO) of sampling adequacy was .87, and Bartlett test of sphericity was highly significant, $p<.001$. Still, the factors derived from data completely differed from the English version of the scale. Analysis showed that negated items from the original scale loaded on one factor that explain $15.43 \%$ of variance, while positive items loaded on other factor that explains $33.58 \%$ of variance (Table 6). Correlation between factors was 0.137 .

Factor analysis on a sample from homes for elderly and disabled

Because of the difference in Croatian and English sample, and the fact that most of the previous researches were made on nursing students, nurses and caregivers, another analysis was made. Second analysis was based only on results gathe-

Table 7. Confirmatory factor analysis with two factors (only participants from home for elderly and disabled, $N=84$ )

\begin{tabular}{|c|c|c|c|}
\hline & \multicolumn{2}{|c|}{ FACTORS } & \multirow{2}{*}{$\begin{array}{l}\text { Commu- } \\
\text { nalities }\end{array}$} \\
\hline & 1 & 2 & \\
\hline Izbjegao bi kontakt s uzrujanom dementnom osobom. & .76 & & .59 \\
\hline Frustriran sam jer ne znam kako pomoći dementnim osobama & .69 & & .45 \\
\hline Mogu ležerno dodirivati osobe s demencijom. & .65 & & .56 \\
\hline Osjećam se opušteno u blizini dementnih osoba. & .62 & & .52 \\
\hline Osjećam se samopouzdano u blizini dementnih osoba. & .61 & & .44 \\
\hline Ne mogu zamisliti da se moram brinuti o dementnoj osobi. & .61 & & .52 \\
\hline Nisam dovoljno upoznat s demencijom. & .53 & & .27 \\
\hline Bojim se dementnih osoba. & .52 & & .48 \\
\hline Ne osjećam se ležerno u blizini osobe s demencijom. & .34 & & .13 \\
\hline Možemo učiniti mnogo kako bi poboljšali život dementnih osoba. & & .73 & .52 \\
\hline Moguće je uživati u druženju s dementnom osobom. & & .66 & .50 \\
\hline Važno je znati protekli život dementne osobe. & & .66 & .41 \\
\hline Svaka osoba s demencijom ima različite potrebe. & .31 & .64 & .41 \\
\hline Osobe s demencijom mogu biti kreativne. & & .58 & .36 \\
\hline Dementne osobe mogu osjetiti kada je netko dobar prema njima. & & .53 & .41 \\
\hline Osobe s demencijom vole imati poznate predmete u blizini. & & .52 & .39 \\
\hline Divim se vještinama suočavanja s bolesti kod dementnih osoba & & .42 & .20 \\
\hline Dementne osobe mogu uživati u životu. & & .36 & .15 \\
\hline Teško ponašanje može biti način komunikacije dementnih osoba. & & .37 & .13 \\
\hline $\begin{array}{ll} & \text { Eigenvalue } \\
\end{array}$ & 5.38 & 2.20 & \\
\hline$\%$ of variance explained & 27.06 & 10.99 & \\
\hline
\end{tabular}


red from employees and users living in home for elderly and infirm. In total, 84 participants were taken into account ( 26 medical, 23 non-medical employees and 35 users). This sample included only medical and non-medical workers that have everyday contact with patients suffering from dementia. Sample also included users of home for elderly and infirm, because they are in everyday contact with dementia patients in common rooms, often communicating alone with them. Although they were not included in previous research, they might be important for patients' wellbeing. Again, confirmatory factor analysis with Oblimin rotation was made, and two factors loaded from the analysis with total of $38.05 \%$ of variance explained. Kaiser-Meyer-Olkin measure (KMO) of sampling adequacy was .77, and Bartlett test of sphericity was highly significant, $p<.001$. First factor explained $27.06 \%$ of variance, while second factor explained $10.99 \%$ of total variance. Factors were almost similar to factors loaded on English sample. First factor, social comfort, consisted of nine items instead of twelve, because item It is rewarding to work with people who have dementia did not load on any factor. Also two items, People with dementia can be creative and Every person with dementia has different needs loaded on dementia knowledge factor instead on social comfort factor. Thus, dementia knowledge factor has ten items. All items can be seen in Table 7. Correlation between factors was 0.174 .

\section{DISCUSSION}

When Croatian version of Dementia attitudes scale was given to employees and users who live in home for elderly and disabled, and have everyday contact with patients suffering from dementia, scale seemed to be reliable for usage. Croatian version of DAS loaded two factors similar to the original: social comfort and dementia knowledge. Social comfort factor consists of nine items, and refer to affective and behavioral component of attitudes toward dementia. Second factor, dementia knowledge, consists of ten items, and refers to cognitive component of attitudes. Although factors loaded from factor analysis slightly differ from the original scale, differences could be attributed to specificity of items. Factors differed in two items: People with dementia can be creative and Every person with dementia has different needs loaded on dementia knowledge factor instead on social comfort factor. Still, the nature of these items could be seen as ambiguous, as both items include knowledge component about the nature of creativity and needs that patients suffering from dementia have. Thus, it seems more appropriate to treat these items as cognitive component of attitudes and part of dementia knowledge factor.

Further results of the study suggest that Croatian version of Dementia Attitudes Scale could be used only on a part of Croatian sample. When analysis was made on the complete sample, two completely new factors, positive and negative attitudes, loaded from factor analysis. All negative items from original scale loaded on 
negative attitudes factor, and it can be supposed that items' valence had large impact on the results. Interestingly, that it is not the first time Croatian sample loaded on positive and negative factors depending on valence of items - similar negative factors for example, loaded on validation of the Croatian Version of the Social Se1f-Esteem Scale (Jelić, 2009) and negative attitudes toward e-learning (Brumini, Mavrinac, Brumini, Špalj \& Blagović, 2012). It seems that sometimes in Croatian sample, valence of the items influences factor structure of the scales and questionnaires, so it could be interesting to test what factors would load if all items had similar valence. Still, it must be emphasized that the results of the study suggest that Croatian version of Dementia attitudes scale cannot be used for every sample, therefore some separate versions of the scale should be made. It seems that more suitable measurement for the first phase of attitudes research study in Croatian general population could be semantic differential technique, with the primary focus on the affective component of attitudes. Semantic differential technique is often used to measure attitudes on a scale between two bipolar adjectives. This technique was previously used to detect reactions of nurses toward patients with severe dementia (Asplund \& Norberg, 1993) and to detect nurses' attitudes toward people suffering from dementia (Norbergh et al., 2006). For example, Norbergh et al. (2006) gave participants 57 bipolar pairs of adjectives on 7-point linear scale, and their task was to indicate the degree of agreement with the given pairs. Because Croatian sample without everyday contact with patients suffering from dementia shows a clear positive-negative attitudes structure, it seems appropriate to give them every item in both polarity shapes, and after that estimate dimensions of attitudes toward dementia in more general population. It can be assumed that, if participants would be given bipolar pairs, this positive-negative structure (probably estimated by one-polarity items) would be eliminated. Results gained by semantic differential technique could be a good base for further research of attitudes toward dementia in the general population. As it was indicated before, second option for elimination of positive-negative factors is to give participants all items from original Dementia attitudes scale in the same polarity (positive form) and to check the structure of that scale. If there would be no difference in polarity between items, it could be assumed that factors would be more similar to the original factors from DAS.

One limitation of the study was that participants were not simultaneously given some other, similar research tool, to which DAS results could be compared. Together with the DAS, participants were given a more general questionnaire about the necessity of better education about dementia. At that time, Croatian version of Approaches to Dementia Questionnaire (ADQ; Lintern, Woods \& Phair, 2000) was still in preparation. Since research was conducted at the time when huge amount of healthcare workers were leaving Croatia, and lots of participants who had taken part in the study were no longer available, there was no option of longitudinal study. Still, there is a significant need to compare results of DAS with similar scales and questionnaires. Firstly, it would be necessary to compare DAS with the above 
mentioned ADQ questionnaire, as ADQ is in practical use in health systems (e.g. Great Britain), to investigate validity of Croatian DAS version and potential correlations with two factors from $\mathrm{ADQ}$, hope and recognition of personhood. Another scale should be compared to knowledge factor form DAS - Alzheimer's Disease Knowledge Scale, ADKS (Carpenter, Balasis, Otilingam, Hanson \& Gatz, 2009). ADKS is a 30-item scale that covers wide range of knowledge related to dementia: risk factors, assessment and diagnosis, symptoms, course, life impact, caregiving, treatment and management. As ADKS was found to have adequate reliability and validity it seems appropriate tool to compare with DAS. Still, there are no Croatian versions of both mentioned scales, what emphasize the need to increase the research in this area. Also, it is recommended to investigate DAS scale in nursing students population, to address students' attitudes toward dementia prior to their employment in the medical sector, in order to clearly indicate the crucial direction of students' education.

In conclusion, Croatian version of DAS should be used to estimate attitudes toward dementia only in populations that have everyday contact with patients suffering from dementia. For further research in this population, and in addition to Croatian version of Dementia attitudes scale, it could be useful to also use the dementia Cares styles Questionnaire (CSQ; Brooker, Foster, Banner, Payne \& Jackson, 1998) which are based on everyday care situations. CSQ shows four different styles of care: medical or disease focused, normalizing or not accounting for the person's disability, behavioral (e.g. ignoring inappropriate behavior), and person-centered or holistic approach. Previous researches showed connection between attitudes and cares styles (Macdonald \& Woods, 2005), and cares styles in dementia patients were not investigated in Croatia. On the other hand, results from more general population show positive-negative structure, which can be highly indicative of the lack of adequate knowledge and potentially deranged structure of attitudes toward dementia. Lack of clear affective-behavioral-cognitive component distinction could appear because of deficiency of education and knowledge about dementia in more general population.

\section{CONCLUSION}

Validation of Croatian version of Dementia attitude scale (DAS) showed that it cannot be used on every sample. Factor analysis on a sample that is in everyday contact with patients suffering from dementia revealed almost identical structure as in the original sample with two factors, social comfort and dementia knowledge. There is a difference in two items, People with dementia can be creative and Every person with dementia has different needs, which loaded on dementia knowledge factor instead on social comfort (as in original scale). On the other hand, when sample consisted of general population and health workers, all without everyday contact 
with patients suffering from dementia, DAS showed different structure, with clear positive and negative attitudes factors. Consequently, DAS should be additionally explored within different samples, and results should be compared to scales with related topics.

\section{REFERENCES}

Askham, J. (1995). Making sense of dementia: careers' perceptions. Aging \& Society, 15, 103-114.

Asplund, K., Norberg, A. (1993). Caregivers reactions to the psychical appearance of a person in the final stage of dementia as measured by semantic differentials. International Journal of Ageing and Human Development, 37, 205-215.

Astrom, S., Nilsson, M., Norberg, A., Sandman, P.-O., Winblad, B. (1991). Staff burnout in dementia care - relations to empathy and attitudes. Journal of nursing studies, 28 , $65-75$

Bowers, B, Esmond, S, Jacobson, N. (2000). The relationship between staffing and quality in long-term care facilities: Exploring the views of nurse sides: Journal of Nurse Care Quality, 14, 55-64.

Breckler, S.J. (1984). Empirical validation of affect, behavior, and cognition as distinct components of attitude. Journal of Personality and Social Psychology, 47, 1191-1205.

Brodaty, H., Draper B., Low, L.-F. (2003). Nursing home staff attitudes towards residents with dementia: strain and satisfaction with work. Journal of Advanced Nursing, 44, 583-590.

Brooker, D., Foster, N., Banner, A., Payne, M., Jackson, L. (1998). The efficacy of Dementia Care Mapping as an audit tool: report of a 3-year British NHS evaluation. Aging and Mental Health, 2, 60-70.

Brumini, G., Mavrinac, M., Brumini, M., Špalj S., Blagović, B. (2012). Oblikovanje i validacija upitnika kojim se mjeri stav studenata prema e-učenju. Medicina fluminensis, 48, 48-56.

Carpenter, B.D., Balasis, S., Otilingam, P.G., Hanson P.K., Gatz, M. (2009). The Alzheimer 's Disease Knowledge Scale: Development and Psychometric Properties. The Gerontologist, 49, 236-247.

Doblhammer, G., Fink A., Fritze, T. (2015). Short-term trends in dementia prevalence in Germany between the years 2007 and 2009. Alzheimer's and Dementia, 11, 291-299.

Gilić, A., Perinčić, R., Kovač, I. (2008). Broj hospitalizacija poradi demencija i organskog psihosindroma na Psihijatrijskom odjelu Opće bolnice u Zadru kroz 20 godina. Medica Jadertina, 38, 33-39.

Gustin, M., Žuvela, I., Jerinić, A., Roso, M., Kunić, I. (2015). Incidencija demencije u Domu umirovljenika Dubrovnik - čimbenik uključivanja u Mental Health Gap Action program Svjetske zdravstvene organizacije. Sestrinski glasnik, 20, 128-132.

Jelić, M. (2009). Validacija hrvatske verzije Skale socijalnog samopoštovanja. Migracijske i etničke teme, 25, 237-262. 
Kada, S., Nygaard, H.A., Mukesh B.N., Geitung, J.T. (2009). Staff attitudes towards institutionalised dementia residents. Journal of Clinical Nursing, 18, 2383-2392.

Kahana, E., Kinney J.M., Kercher, K., Kahana B., Tinsley, V.V., King C., Stuckey J.C., Ishler K.J. (1996). Predictors of attitudes toward three target groups of elderly persons: the well, the physically ill, and patients with Alzheimer's disease. Journal of Aging and Health, 8, 27-53.

Kite, M.E., Stockdale, G.D., Whitley Jr., B.E., Johnson, B.T. (2005). Attitudes toward younger and older adults: an updated meta-analytic review. Journal of Social Issues, 61, 241-266.

Kleinman, L. Frank, L., Ciesla, G., Rupnow M., Brodaty, H. (2004). Psychometric performance of an assessment scale for strain in nursing care: The M-NCAS. Health and Quality of Life Outcomes, 2, 62.

Langdon, S.A., Eagle, A., Warner, J. (2007). Making sense of dementia in the social world: a qualitative study. Social Science and Medicine, 64, 989-1000.

Leung, J.L.M., Sezto, N.W., Chan, W.C., Cheng, S.P., Tang S.H., Lam, L.C.W. (2013). Attitudes and perceived competence of residential care homes staff about dementia care. Asian Journal of Gerontology \& Geriatric, 8, 21-29.

Lintern, T., Woods, B., Phair, L. (2000). Before and after training: a case study of intervention. Journal of Dementia Care, 8, 15-17.

Lundquist, T.S., Ready, R.E. (2008). Young adult attitudes about Alzheimer's disease. American Journal of Alzheimer's Disease and Other Dementias, 23, 267-273.

Macdonald, A.J.D., Woods, R.T. (2005). Attitudes to dementia and dementia care held by nursing staff in U.K. "non-EMI" care homes: what difference do they make? International Psychogeriatrics, 17, 383-391.

McCabe, M., You, E., Tatangelo, G. (2016). Hearing Their Voice: A Systematic Review of Dementia Family Caregivers' Needs. The Gerontologist, DOI: 10.1093/geront/gnw078.

Moyle, W., Murfield, J.E., Griffiths S.G., Venturato, L. (2011). Care staff attitudes and experiences of working with older people with dementia. Australasian Journal on Ageing, 30, 186--190.

Nakahira, M., Moyle, W., Creedy D., Hitomi, H. (2009). Attitudes toward dementia-related aggression among staff in Japanese aged care settings. Journal of Clinical Nursing, 18, 807-816.

Norbergh, K.-G., Helin, Y., Dahl, A., Hellzen, O., Asplund, K. (2006). Nurses’ attitudes towards people with dementia: the semantic differential technique. Nursing Ethics, 13, 264-274.

O'Connor, M.L., McFadden, S.H. (2010). Development and psychometric validation of the Dementia attitudes scale. International Journal of Alzheimer's disease, Article ID 454218; doi:10.4061/2010/454218.

Ostrom, T. (1969). The relationship between the affective, behavioral, and cognitive components of attitude. Journal of Experimental Social Psychology, 5, 12-30.

Perko, G., Tomek-Roksandić, S., Mihok, D., Puljak, A., Radašević, H., Tomić, B., Čulig, J. (2005). Četiri javnozdravstvena problema u zaštiti zdravlja starijih osoba u Hrvatskoj. MEDICU, 14, 205-217. 
Samsi, K., Manthorpe, J. (2014). Care pathways for dementia: current perspectives. Clinical Interventions in Aging, 9, 2055-2063.

Shin, J.H., Seo, H.-J., Kim, K.H., Kim, K.-H., Lee, Y. (2015). Korean nursing students: a cross-sectional survey. BMC Nursing, DOI 10.1186/s12912-015-0116-4.

Wortmann, M. (2014). New global prevalence data on dementia. Alzheimer's and Dementia, 10, $\mathrm{P} 279$.

Ziegler U., Doblhammer, G. (2009). Prevalence and incidence of dementia in Germany--a study based on data from the public sick funds in 2002. Gesundheitswesen, 71, 281-290.

Zimmerman, S.I., Sloane, P.D. (1999). Optimum residential care for people with dementia. Generations, 23, 62-68.

Zimmerman, S., Williams, C.S., Reed, P.S., Boustani, M., Preisser, J.S., Heck E.,Sloane, P.D. (2005). Attitudes, Stress, and Satisfaction of Staff Who Care for Residents with Dementia. The Gerontologist, 45, 96-105.

\title{
VALIDACIJA HRVATSKE VERZIJE SKALE STAVOVA O DEMENCIJI (DAS)
}

\begin{abstract}
Sažetak
Demencija značajno utječe na kognitivno i bihevioralno funkcioniranje osobe te je stoga značajan medicinski problem, a posljednjih je godina uočen značajan porast broja oboljelih od demencije. U Hrvatskoj, većina oboljelih smještena je u domovima za starije i nemoćne osobe, nespecijaliziranim ustanovama koji nemaju adekvatno educirano osoblje. Stavovi o demenciji značajan su faktor za adekvatnu skrb o oboljelima od demencije, no u Hrvatskoj nisu vršena ispitivanja te ne postoji adekvatan instrument. Stoga je cilj rada validirati Skalu stavova o demenciji, koju su razvili O'Connor i McFadden (2010) na hrvatskome jeziku i uzorku. U istraživanju su sudjelovali zaposlenici i korisnici domova za starije i nemoćne osobe i uzorak iz opće populacije. Rezultati na populacijama koje su u svakodnevnom kontaktu s oboljelima o demencije pokazali su konzistentnost s originalnom skalom u deriviranom faktorima te se hrvatska verzija Skale stavova o demenciji može koristiti kao adekvatan instrument na ovim populacijama. Ipak, validacija na ukupnom uzorku koji je uključivao opću populaciju pokazuje odstupanja u faktorima i grupiranje čestica prema njihovoj valenciji. Stoga su rezultati visoko sugestivni te upućuju na potrebu za razlikovanjem populacija i razdvojenim ispitivanjem stavova o demenciji kod različitih skupina.

Ključne riječi: stavovi o demenciji, Skala stavova o demenciji, znanje o demenciji, socijalna ugodnost
\end{abstract}

Prihvaćeno za tisak: 30. 04. 2016. 